\title{
Differential gene expression response of synovial fibroblasts from temporomandibular joints and knee joints to dynamic tensile stress
}

\author{
Ute Nazet ${ }^{1}$ (D) Patrick Neubert ${ }^{2}$. Valentin Schatz ${ }^{2}$ Susanne Grässel ${ }^{3}$ (D) · Peter Proff ${ }^{1}$ Jonathan Jantsch ${ }^{2}$. \\ Agnes Schröder ${ }^{1}$ (D) $\cdot$ Christian Kirschneck ${ }^{1}$
}

Received: 30 November 2020 / Accepted: 18 April 2021 / Published online: 17 June 2021

(c) The Author(s) 2021

\begin{abstract}
Purpose Apart from other risk factors, mechanical stress on joints can promote the development of osteoarthritis (OA), which can also affect the temporomandibular joint (TMJ), resulting in cartilage degeneration and synovitis. Synovial fibroblasts (SF) play an important role in upkeeping joint homeostasis and OA pathogenesis, but mechanical stress as a risk factor might act differently depending on the type of joint. We thus investigated the relative impact of mechanical stress on the gene expression pattern of SF from TMJs and knee joints to provide new insights into OA pathogenesis.

Methods Primary SF isolated from TMJs and knee joints of mice were exposed to mechanical strain of varying magnitudes. Thereafter, the expression of marker genes of the extracellular matrix (ECM), inflammation and bone remodelling were analysed by quantitative real-time polymerase chain reaction (RT-qPCR).

Results SF from the knee joints showed increased expression of genes associated with ECM remodelling, inflammation and bone remodelling after mechanical loading, whereas TMJ-derived SF showed reduced expression of genes associated with inflammation and bone remodelling. SF from the TMJ differed from knee-derived SF with regard to expression of ECM, inflammatory and osteoclastogenesis-promoting marker genes during mechanical strain.

Conclusions Osteoarthritis-related ECM remodelling markers experience almost no changes in strain-induced gene expression, whereas inflammation and bone remodelling processes seem to differ depending on synovial fibroblast origin. Our data indicate that risk factors for the development and progression of osteoarthritis such as mechanical overuse have a different pathological impact in the TMJ compared to the knee joint.
\end{abstract}

Keywords Osteoarthritis $\cdot$ Disease induction $\cdot$ Joint diseases $\cdot$ Animal model $\cdot$ Mechanical loading

Availability of data and material All data are available upon request from the corresponding author.

Code availability Available on request.

Ute Nazet

ute.nazet@ukr.de

1 Department of Orthodontics, University Medical Centre of Regensburg, Regensburg, Germany
Institute of Clinical Microbiology and Hygiene, University Hospital of Regensburg, Regensburg, Germany

3 Department of Orthopaedic Surgery, Experimental Orthopaedics, Centre for Medical Biotechnology, University of Regensburg, Regensburg, Germany 


\section{Differenzielle Genexpression synovialer Fibroblasten aus Kiefergelenk und Kniegelenk als Reaktion auf dynamische Zugspannung}

\section{Zusammenfassung}

Hintergrund Mechanische Belastung von Gelenken kann abgesehen von anderen Risikofaktoren die Entwicklung von Osteoarthrose (OA) fördern. Dies kann auch das Kiefergelenk (TMJ) betreffen und zu Knorpeldegeneration und Synovitis führen. Synoviale Fibroblasten (SF) spielen eine wichtige Rolle bei der Aufrechterhaltung der Gelenkhomöostase und bei der OA-Pathogenese, aber je nach Art des Gelenks kann sich mechanische Belastung als Risikofaktor unterschiedlich auswirken. Wir untersuchten daher den relativen Einfluss von mechanischem Stress auf das Genexpressionsmuster von SF aus dem Kiefergelenk und dem Kniegelenk, um neue Erkenntnisse zur OA-Pathogenese zu gewinnen.

Methoden Aus Kiefer- und Kniegelenken von Mäusen isolierte primäre SF wurden mechanischer Belastung unterschiedlichen Ausmaßes ausgesetzt. Dabei wurde mittels RT-qPCR (,quantitative real-time polymerase chain reaction“) die Expression von Markergenen der extrazellulären Matrix (ECM), der Entzündung und des Knochenumbaus analysiert.

Ergebnisse In SF aus den Kniegelenken war nach mechanischer Belastung die Expression von Genen, welche mit ECM-Umbau, Entzündung und Knochenumbau assoziiert sind, erhöht, während in aus Kiefergelenken isolierten SF die Expression von in Entzündung und Knochenumbauprozesse involvierten Genen reduziert war. Des Weiteren unterschieden sich während der mechanischen Belastung TMJ-SF und Kniegelenk-SF hinsichtlich der Expression von Markergenen für ECM, Entzündung und Förderung der Osteoklastogenese.

Schlussfolgerungen Osteoarthrosebezogene ECM-Remodellierungsmarker erfahren fast keine Veränderungen in der belastungsinduzierten Genexpression, wohingegen Entzündungs- und Knochenumbauprozesse in Abhängigkeit von der Herkunft der SF unterschiedlich beeinflusst zu sein scheinen. Unsere Daten deuten darauf hin, dass Risikofaktoren für die Entwicklung einer OA und deren Fortschreiten, wie z.B. mechanische Überbeanspruchung, im TMJ einen anderen pathologischen Einfluss haben als im Kniegelenk.

\section{Schlüsselwörter Osteoarthrose $\cdot$ Entstehen einer Erkrankung $\cdot$ Gelenkerkrankungen $\cdot$ Tiermodell $\cdot$ Mechanische Belastung}

\section{Introduction}

Full movement and flexibility of the human body is enabled by various types of joints. Their structural composition, however, is very specific. There are synovial joints imbedded in an articular capsule interconnecting bones as well as fibrous and cartilaginous joints, characterised by their connective tissue appearance [34]. Joint disorders such as osteoarthritis impede joint functionality of major joints within the human body, including the temporomandibular joint (TMJ), thus affecting quality of life as well as performance effectiveness [22, 29]. Osteoarthritis affects subjects with increasing age, joints exposed to mechanical stress and depends on dietary food intake and factors of metabolic and genetic origin [13, 18, 19, 27]. As osteoarthritis diminishes effective performance ability and quality of life, research in this topic promises pain relief as well as the determination of the impact of various factors on osteoarthritis development and progression.

For several years a variety of treatment options promising patients pain relief and improvement of joint functionality have been established. Apart from general recommendations, such as lifestyle changes, also pain-relieving medication (e.g. non-steroidal anti-inflammatory drugs) and supportive treatments (e.g. transcutaneous electrical nerve stimulation, physiotherapist-guided manual therapy or assistive devices) can reduce pain. Another noninvasive alternative treatment option is laser therapy and low intensity pulsed ultrasound, as they promise pain relief, while patients experience few side effects [2, 9, 31, 44]. Furthermore in vivo OA-model studies indicate favourable effects by the application of ultrasound treatment, concerning cartilage repair, extracellular matrix destruction and vascularisation $[15,16,46]$. Surgical treatment options are considered if noninvasive options show no effect and the joint is severely damaged. In these cases, minimally invasive procedures can be performed to remove scar tissue, reshape the joint or relieve swelling, while removing inflammatory byproducts. In case of open surgery, total joint replacement can be performed as well as joint fusing and osteotomy.

In general, osteoarthritis is an illness based on a misbalanced interplay between several cell populations located in the joints $[6,55]$. This imbalance supports cartilage degradation, osteophyte formation, subchondral bone reduction and synovial inflammation. Currently, the role of the synovial membrane in osteoarthritis development and progression is being investigated with increasing interest. Synovial fibroblasts, which constitute the major cell population of the synovial membrane, are involved in joint lubrication, tissue homeostasis and nourishment [7, 14, 30]. 
A clinical indicator of osteoarthritis among others is synovitis associated with a thickened and inflammatory active synovial membrane. During inflammation and osteoarthritis, the synovial membrane undergoes changes causing enhancement and induction of inflammation, altered joint lubrication composition and a signalling shift in bone remodelling [48]. Apart from research on human primary cells, derived from osteoarthritis-affected patients and patients without osteoarthritis, research focuses on model-organismderived primary cells. Hence, major research regarding osteoarthritis development and progression is performed on knee joints. But also the TMJ can be affected by arthritic changes with a high impact on quality of life. Beside the fact that both joints belong to the family of synovial joints, they differ in their embryonic development.

During embryogenesis, the structures of the knee joint develop from the outer and central mesenchyme, forming the joint capsule, ligaments and synovial cavities [35]. In contrast, the TMJ emerges from the ectoderm being guided by Hedgehog signalling pathways, while the secondary cartilage develops [28]. Apart from differences in development, both joints also differ in their mode of operation. In the knee joint, movement is only possible in a single axis, defined by fixating tendons, muscles and structural components, categorizing it as a member of the hinge-joint family
[34]. In contrast, the TMJ is a hinge and sliding joint, as the interplay between the disc, the glenoid fossa of the temporal bone and the connective tissue enables joint articulation on a single plane and axis $[1,51]$. These differences in mechanical and structural composition (single axis movement versus single plane and axial movement), as well as embryogenic development may have an impact on the factors that induce osteoarthritis. Therefore, we analysed the differential effects of different mechanical stimuli in the context of osteoarthritic inflammation of the knee and TMJ joint on extracellular matrix composition and bone remodelling in synovial fibroblasts derived from temporomandibular joints and compared the findings to data derived from knee joints.

\section{Material and methods}

\section{Isolation of synovial fibroblasts}

For isolation of synovial fibroblasts, wildtype BL/6 mice (male, age: 9 weeks) were killed and dissected conforming to national and institutional regulations. The knee capsule was opened by radial cuts above the patella, and the patella with attached synovial tissue was harvested in ice-cold Dulbecco's modified Eagle's medium (DMEM; D5671, a
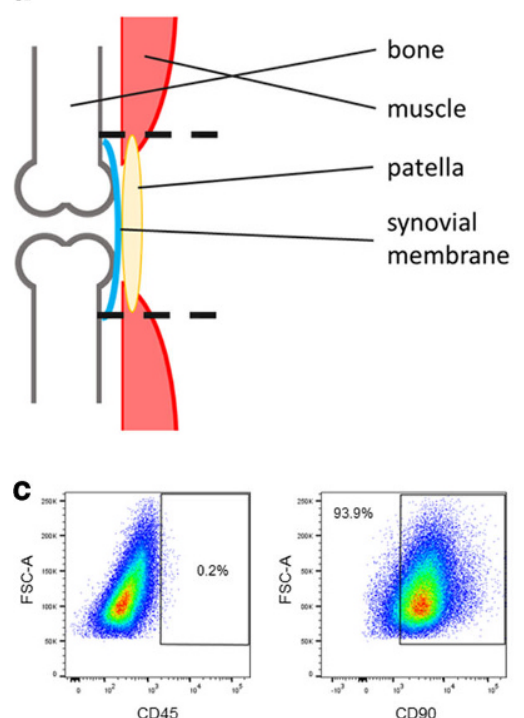

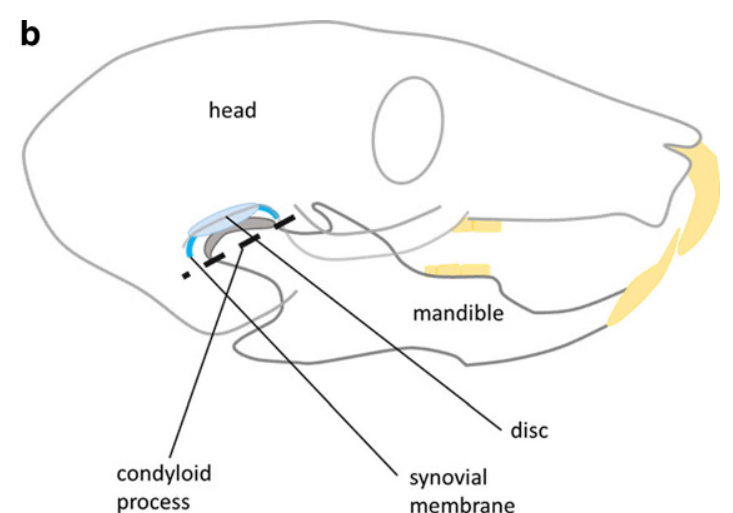

d
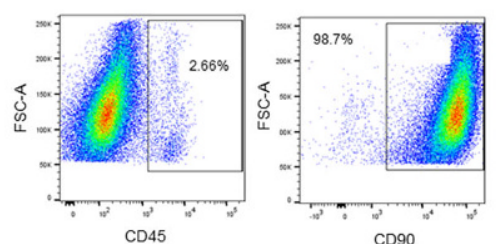

Fig. 1 Isolation and characterisation of murine synovial fibroblasts (SF) derived from the knee and temporomandibular joint (TMJ). After removal of superficial tissue, the joint capsule of the knee (a) was opened to dissect the synovial membrane, while in the capsule of the mandibular joint (b) the synovial tissue of the TMJ was located. After several days, outgrowing of spindle-shaped cells was observed from TMJ samples and knee samples. The proportion of cells positive for leukocyte-specific antigens (CD45) and fibroblast-specific antigens (CD90) was determined via fluorescence-activated cell sorting (FACS) analysis (c primary knee SF; d primary TMJ SF)

Abb. 1 Isolierung und Charakterisierung von murinen synovialen Fibroblasten (SF) aus dem Knie- und dem Kiefergelenk (TMJ). Nach Entfernung des oberflächlichen Gewebes wurde die Gelenkkapsel des Knies (a) geöffnet, um die Synovialmembran zu sezieren, während in der Kapsel des TMJ (b) das entsprechende synoviale Gewebe zu finden war. Nach einigen Tagen wurde sowohl in den TMJ-als auch in den Kniegelenkproben ein Auswachsen spindelförmiger Zellen beobachtet. Der Anteil an für leukozytenspezifische (CD45) und fibroblastenspezifische (CD90) Antigene positiven Zellen wurde mittels FACS(,fluorescence-activated cell sorting“)-Analyse bestimmt (c primäre Kniegelenk-SF, d primäre TMJ-SF) 
Sigma Aldrich, St. Louis, MO, USA), supplemented with 1\% L-glutamine solution (L-Glut; G7513, Sigma Aldrich, St. Louis, MO, USA) and 1\% antibiotic antimycotic (AA; A5955, Sigma Aldrich, St. Louis, MO, USA; Fig. 1a). For isolation of the temporomandibular synovial tissue, first the superficial masseter muscle was removed, providing open access to the condyloid process located in the socket of the mandibular fossa beneath the zygomatic process of the temporal bone. The condyloid process was lifted and the condylar head including the articular disc and attached synovial tissue was extracted and transferred to icecold DMEM (Fig. 1b). For all dissection steps, a Nikon SMZ 1500 microscope (Nikon, Minato, Tokyo, Japan) was used. After dissection, the harvested tissues were washed twice with Dulbecco's phosphate buffered saline (PBS; 14190-094, Gibco, Thermo Fisher Scientific, Waltham, MA, USA), supplemented with $1 \%$ antibiotic antimycotic in a sterile laminar airflow cabinet. For digestion, the respective bilateral knee or TMJ tissue of five animals was pooled (10 knees or $10 \mathrm{TMJs}$ ), cut into small pieces and transferred to DMEM (supplemented with $10 \%$ fetal bovine serum (FBS; P30-3302, Pan Biotech, Aidenbach, Germany), $1 \%$ L-Glut, $1 \%$ AA and $0.1 \%$ collagenase IV (C4-28, Biochrom, Merck Millipore, Burlington, MA, USA)) for at least $2 \mathrm{~h}$ at $37^{\circ} \mathrm{C}$ [3]. To improve digestion, the samples were mixed several times during incubation. After incubation, the samples were centrifuged and the pellet was resuspended in fresh DMEM (supplemented with $10 \% \mathrm{FBS}, 1 \% \mathrm{AA}, 1 \% \mathrm{~L}-$ Glut and $1 \%$ ascorbic acid). Tissue pieces and floating cells were plated in separate cell culture containers, which had been coated the day before with collagen I (ALX-522-435-0020, Enzo Life Sciences, Lörrach, Germany). After several days, outgrowing cells with spindle-shape appearance could be observed.

\section{Characterisation of synovial fibroblasts}

For characterisation of harvested cells, the presence of fibroblastic antigens (CD90, dilution 1:100) and absence of leukocytic antigens (CD45, dilution 1:100; Fig. 1c, b) was determined [3, 42].

Gene expression was verified by semiqantiative PCR analysis. RNA was harvested and cDNA was generated, followed by PCR analysis: 2 ng cDNA were supplemented with $0.25 \mu 110 \mathrm{pmol}$ forward primer, $0.25 \mu \mathrm{l} 10 \mathrm{pmol}$ reverse primer (Supplemental Table 1), $1 \mu \mathrm{l} 10 \times$ buffer $+\mathrm{MgCl}_{2}$ (14800100; Roche), $0.2 \mu \mathrm{l} 200 \mu \mathrm{M}$ dNTPs (L785.1/2; CarlRoth), $0.1 \mu \mathrm{l}$ Taq-Pol (39469200; Roche) and nucleasefree water up to a final volume of $10 \mu$ l. After initiation $\left(95^{\circ} \mathrm{C}, 5 \mathrm{~min}\right), 40$ cycles of ligation and elongation $\left(95^{\circ} \mathrm{C}\right.$ for $20 \mathrm{~s}, 65^{\circ} \mathrm{C}$ for $30 \mathrm{~s}$ ) were applied. Finally, products were stored at $4{ }^{\circ} \mathrm{C}$ until further application. Product analysis was done on a $1 \%$ agarose $1 \times$ TAE gel (Tris-acetate-
EDTA; 50×TAE: $2 \mathrm{M}$ Tris, 50mM EDTA, $1 \mathrm{M}$ glacial/ acetic acid; pH 8.3; supplemental Fig. 1) [26, 54].

Antigen presence was determined by FACS (fluorescence-activated cell sorting; BD FACS Canto ${ }^{\mathrm{TM}}$ II, BD Biosciences, San Jose, CA, USA) analysis. To this aim, 150,000 cells were harvested, washed and resuspended in $50 \mu \mathrm{l} 1 \times$ phosphate-buffered saline, supplemented with $1 \mu \mathrm{l}$ FC-Block (101319, Biolegend, San Diego, CA, USA) and incubated for $5 \mathrm{~min}$ at $4{ }^{\circ} \mathrm{C}$. Subsequently, $1 \mu \mathrm{l}$ of the antibodies of interest was added (CD90, 105327, Biolegend, San Diego, CA, USA; CD45, 109831, Biolegend, San Diego, CA, USA) and the cells were incubated for a further $30 \mathrm{~min}$ at $4{ }^{\circ} \mathrm{C}$. After incubation, $1 \mathrm{ml} \mathrm{PBS}$ was added and the cell suspension was centrifuged $(5 \mathrm{~min}$, $300 \mathrm{~g}, 4^{\circ} \mathrm{C}$ ). After discarding the supernatant, the pellet was resuspended in $100 \mu \mathrm{PBS}$ and immediately analysed via FACS. All steps were performed in dark conditions.

\section{Dynamic stretching protocols}

The experimental dynamic stretching assay consisted of three distinct stretching protocols, containing two identical blocks of stretching [37, 41]. After preincubating 70,000 synovial fibroblasts per well on a collagen-I-coated 6-well plate (BF-3001C, Flexcell, Burlington, NC, USA) for $24 \mathrm{~h}$, the first block of $16 \mathrm{~h}$ of stretching was applied, followed by a break of $8 \mathrm{~h}$ and a second block of stretching (16h), which was also the final one. In the moderate stretching protocol (SM; Fig. 2a), cells were stretched at a frequency of $0.2 \mathrm{~Hz}$ and an amplitude of $2 \%$ per block. In the advanced stretching protocol (SA; Fig. 2c), cells were stretched at a frequency of $0.5 \mathrm{~Hz}$ and an amplitude of $15 \%$, while in the mixed stretching protocol (SM/SA; Fig. 2b), cells were stretched at a frequency of $0.2 \mathrm{~Hz}$ and $2 \%$ for $2 \mathrm{~h}$ and $0.5 \mathrm{~Hz}$ and $15 \%$ for $2 \mathrm{~h}$ in continuous alternation per block. For stretching, a custom-made cell-stretching machine was used, offering a 6-well plate fitting slot and 6 stamps, capable to simultaneously elongate according to a previously compiled stretching protocol (Fig. 2). For the experiments, cells of passages 6 and 7 were used.

\section{Determination of cell number}

After dynamic stretching, synovial fibroblasts were scrapped off the cell culture plate and resuspended in $1 \mathrm{ml}$ PBS. For determination of cell number, $100 \mu \mathrm{l}$ of the cell suspension were mixed with $10 \mathrm{ml} 0.9 \%$ saline and cell number was immediately measured with a Beckman Coulter Counter Z2 (Beckman Coulter GmbH, Krefeld, Germany). 

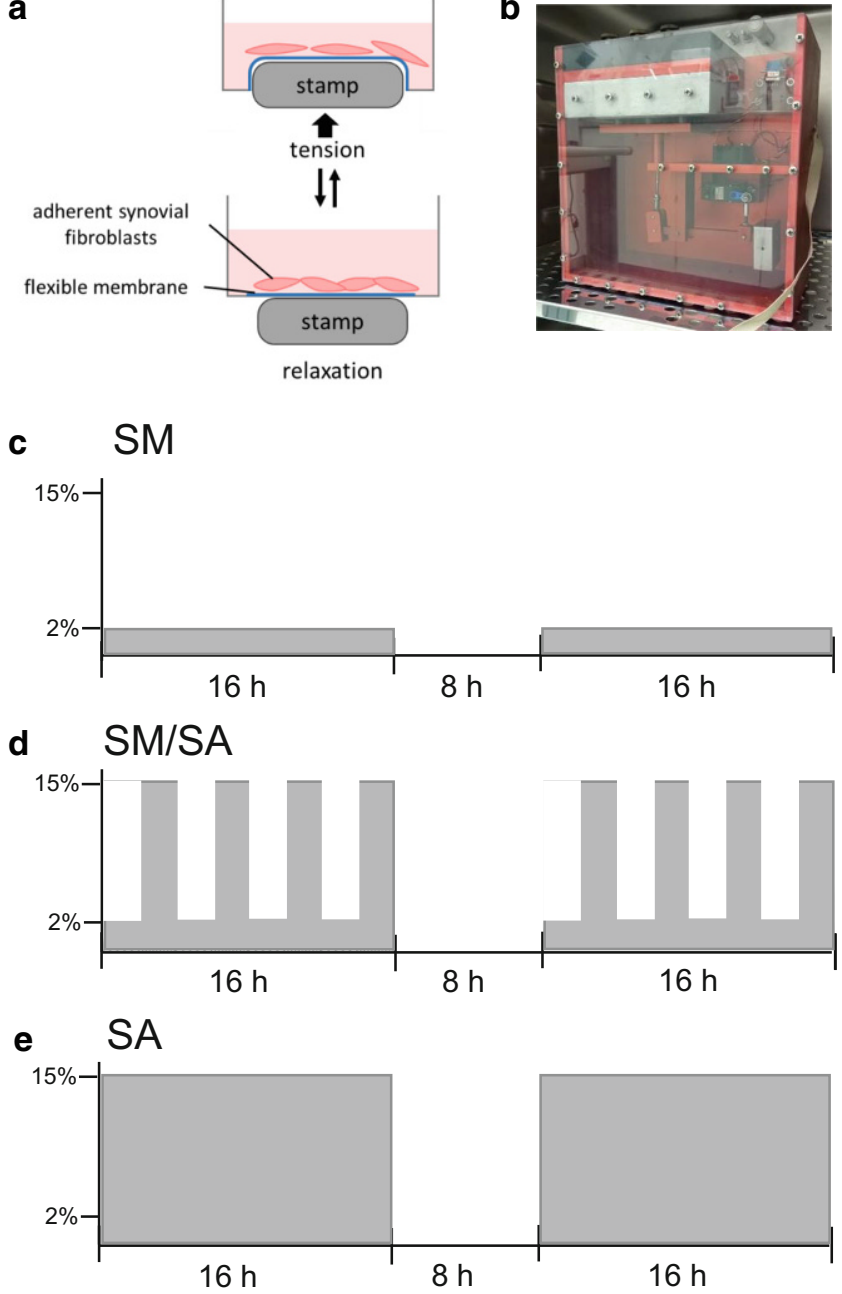

Fig. 2 Visualization of applied dynamic stretching protocols (a) performed in a custom made cell stretching device (b) composed of distinct protocols of moderate stretching (SM; c), mixed stretching $(\mathrm{SM} / \mathrm{SA} ; \mathbf{d})$ and advanced stretching $(\mathrm{SA} ; \mathbf{e})$

Abb. 2 Visualisierung der angewandten dynamischen Dehnungsprotokolle (a), durchgeführt in einem speziell angefertigten Zelldehnungsgerät (b). Die Dehnungsprotokolle bestanden aus Protokollen für moderate (SM; c), gemischte (SM/SA; d) und anspruchsvolle Dehnung $(\mathrm{SA} ; \mathbf{e})$

\section{Determination LDH release}

LDH (Lactate Dehydrogenase Activity) assay was performed following the manufacturer's instructions (0474492 6001, Roche) using the cell culture supernatant after dynamic stretching protocols. Briefly, cell culture supernatant was mixed with $\mathrm{LDH}$ solution ( $22 \mu \mathrm{l}$ catalyst with $1 \mathrm{ml}$ dye) $1: 1$ and incubated for $30 \mathrm{~min}$ at room temperature in the dark. After stopping the reaction by adding stop solution, the absorbance at $490 \mathrm{~nm}$ was measured, using a fluorescent plate reader (Multiscan GO Microplate Spectrophotometer, Thermo Fisher Scientific, Waltham, MA, USA). Background absorbance at $690 \mathrm{~nm}$ was subtracted.

\section{RNA isolation}

We isolated RNA using peqGOLD TriFast ${ }^{\mathrm{TM}}$ (30-2020, Peqlab, VWR, Radnor, PA, USA). Briefly, $500 \mu \mathrm{l}$ peqGOLD TriFast $^{\mathrm{TM}}$ was added per sample and vortexed after addition of $100 \mu \mathrm{l}$ chloroform (102445, Merck, Darmstadt, Germany) for at least $20 \mathrm{~s}$. Approximately $200 \mu \mathrm{l}$ colourless supernatant was transferred to a tube with $500 \mu \mathrm{l}$ precooled isopropanol (20.842.330, VWR, Radnor, PA, USA) and incubated overnight at $-80^{\circ} \mathrm{C}$. Samples were centrifuged for $30 \mathrm{~min}$ at $4{ }^{\circ} \mathrm{C} 13,000 \mathrm{rpm}$ and the obtained pellet was washed twice with $80 \%$ ethanol (32205-1L-M, SigmaAldrich, St. Louis, MO, USA). After the last washing step, the pellet was dried for at least $30 \mathrm{~min}$ and RNA concentration was determined using a NanoPhotometer (N60, Implen, Munich, Germany) after reconstitution in $20 \mu \mathrm{l}$ RNase-free water (T143, Carl Roth, Karlsruhe, Germany).

\section{CDNA synthesis}

To reduce experimental variation, reverse transcription reagents were used as master mix. For one sample, we mixed $1 \mu \mathrm{l}$ oligo-dT18 primer (SO131, Thermo Fisher Scientific, Waltham, MA, USA), $1 \mu \mathrm{l}$ random hexamer primer (SO142, Thermo Fisher Scientific, Waltham, MA, USA), $1 \mu \mathrm{l}$ dNTP mix (L785.2, Carl Roth), $1 \mu$ RNase inhibitor (EO0381, Thermo Fisher Scientific, Waltham, MA, USA), $1 \mu \mathrm{l}$ MLV-reverse transcriptase (M1705, Promega, Madison, WI, USA) and $4 \mu \mathrm{l} 5 \times$ M-MLV-buffer (M1705, Promega). Equal amounts of RNA (50ng) were diluted in a total volume of $5.5 \mu \mathrm{l}$ and mixed with $4.5 \mu \mathrm{l}$ prepared master mix (total volume of cDNA reaction: $10 \mu \mathrm{l}$ ). RNA was transcribed within $60 \mathrm{~min}$ at $37^{\circ} \mathrm{C}$ followed by $2 \mathrm{~min}$ at $95^{\circ} \mathrm{C}$. Finally, the cDNA was diluted with RNAse-free water (T143, Carl Roth, Karlsruhe, Germany) to a final concentration of $1 \mathrm{ng} / \mu \mathrm{l}$ for storage and further semiquantitative and quantitative real-time PCR performance.

\section{Quantitative real-time polymerase chain reaction}

To reduce experimental variation, a master mix of quantitative real-time polymerase chain reaction (RT-qPCR) reagents was used. For each sample, we mixed $7.5 \mu \mathrm{l}$ SYBR ${ }^{\circledR}$ Green JumpStart Taq ReadyMix (S4438, Sigma Aldrich, St. Louis, MO, USA), $0.75 \mu \mathrm{l}$ forward and $0.75 \mu \mathrm{l}$ reverse primer with $5.25 \mu$ l RNAse-free water (T143, Carl Roth). Per sample we applied $13.5 \mu$ per well of a 96-well PCR plate (TW-MT, 712282, Biozym Scientific, Hessisch Oldendorf, Germany), mixed it with $1.5 \mu \mathrm{l}$ cDNA $(1 \mathrm{ng} / \mu \mathrm{l})$ and sealed the plate with a cover (712350, Biozym Scientific, Hessisch Oldendorf, Germany). After initial heating for $5 \mathrm{~min}$ at $95^{\circ} \mathrm{C}$, RT-qPCR was performed in $45 \mathrm{cy}$ cles (each cycle: $10 \mathrm{~s}$ at $95^{\circ} \mathrm{C}, 8 \mathrm{~s}$ at $60^{\circ} \mathrm{C}, 8 \mathrm{~s}$ at $72^{\circ} \mathrm{C}$; 


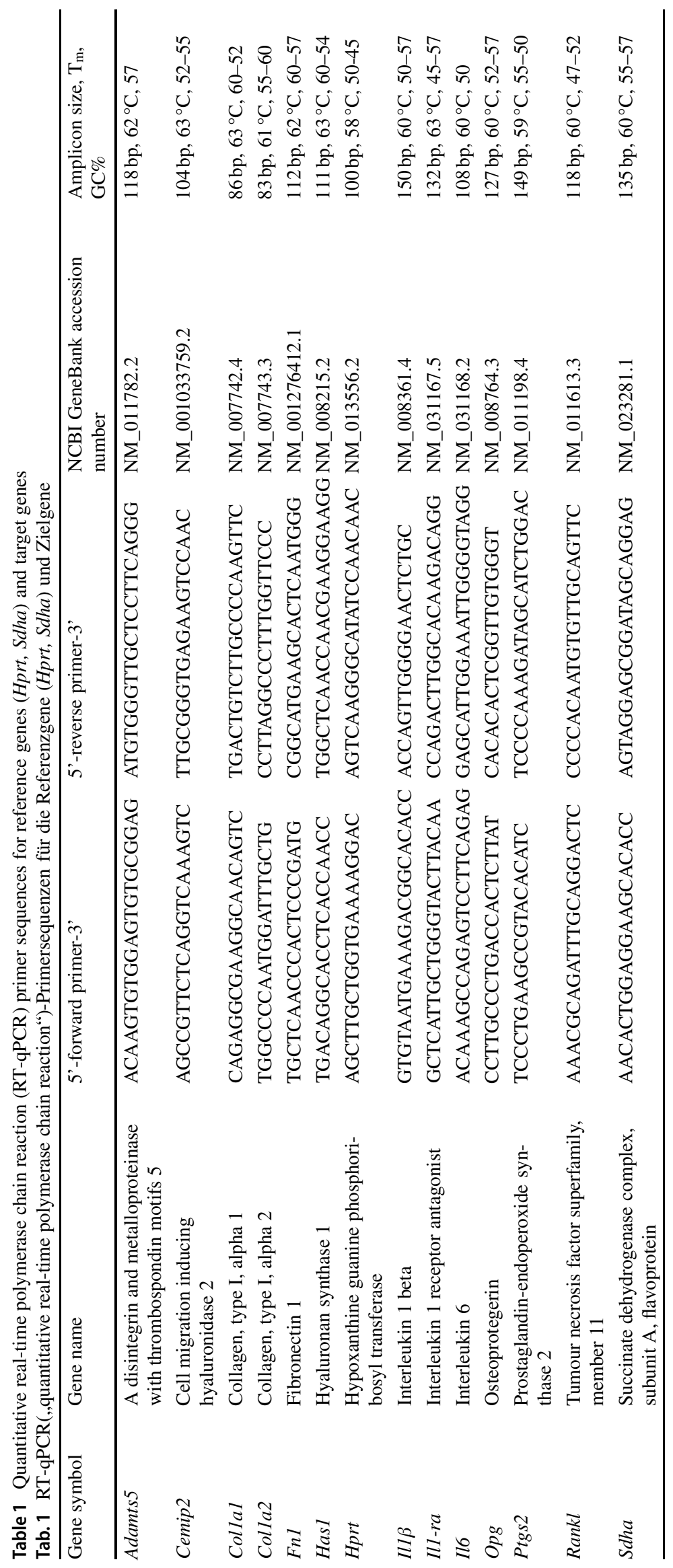


Mastercycler ${ }^{\circledR}$ ep realplex-S thermocycler, Eppendorf AG, Hamburg, Germany). We calculated relative gene expression using a set of two reference genes which proved to be suitable for the used experimental setup based on the $2^{-\Delta \mathrm{Cq}}$ method $(\Delta \mathrm{Cq}=\mathrm{Cq}$ (target gene) $-\mathrm{Cq}$ (geometric mean $\mathrm{Hprt} / \mathrm{Sdha}$ )) $[49,50]$. All primers (Table 1; Eurofins MWG, Ebersberg, Germany) were constructed with NCBI PrimerBLAST [10]. Hprt and Sdha were used as reference genes, as they showed the most stable expression in the experimental setup (unpublished data). For RT-qPCR analysis two technical and at least 3-5 biological replicates and three repetitions per stretching protocol run were performed. The data are presented as fold-change in comparison to the mean gene expression detected in the control group (unstretched cells).

\section{Statistical analysis}

GraphPad Prism version 8.4 for Windows (GraphPad Software, San Diego, CA, USA) was used for statistical analysis. Mixed-effects analysis with Geisser-Greenhouse correction followed by Holm-Sidak's multiple comparison tests was performed to determine differences between knee- and TMJ-derived synovial fibroblasts and Dunett's multiple comparison tests to assess differences between different stretching protocols. Significance level was set at $p<0.05$.

\section{Results}

\section{Synovial fibroblast origin and dynamic stretching}

\section{Impact on cell number and cytotoxicity}

First, we investigated the effects of dynamic stretching on synovial fibroblast number. Cell number was not affected by any tested dynamic stretching protocol in knee(SM: $p=0.6441$; SM/SA: $p=0.4945$; SA: $p=0.5958$ ) and TMJ-derived synovial fibroblasts (SM: $p=0.2314$; SM/SA: $p=0.3650$; SA: $p=0.5640$; Fig. 3a). Accordingly, we detected no differences in number of fibroblasts from the knee or the TMJ (SM: $p=0.2031$; SM/SA: $p=0.2031$; SA: $p=0.6720$ ). In line with cell number, LDH release was not affected by the various dynamic stretching protocols in synovial fibroblasts of knee (SM: $p=0.6441$; SM/SA: $p=0.4945$; SA: $p=0.5958$ ) and TMJ origin (SM: $p=0.6441$; SM/SA: $p=0.4945$; SA: $p=0.5958$; Fig. $3 b$ ), indicating no cytotoxic effects of the dynamic stretching protocols applied.

\section{Impact on extracellular-matrix-remodelling gene expression}

The extracellular matrix consists of fibrous components, various glycoproteins and polysaccharides. The predominant protein family are collagens, which mainly consist of alpha-1 and alpha-2 polypeptide chains. The second largest group are glycosaminoglycans, which can interact with proteins to form proteoglycans. Gene expression of collagen-1-alpha-1 (Collal) was not affected by any dynamic stretching protocol applied on knee- (SM: $p=0.2796$; SM/SA: $p=0.3042$; SA: $p=0.2317$ ) and TMJ-derived synovial fibroblasts (SM: $p=0.9630$; SM/SA: $p=0.3149$;
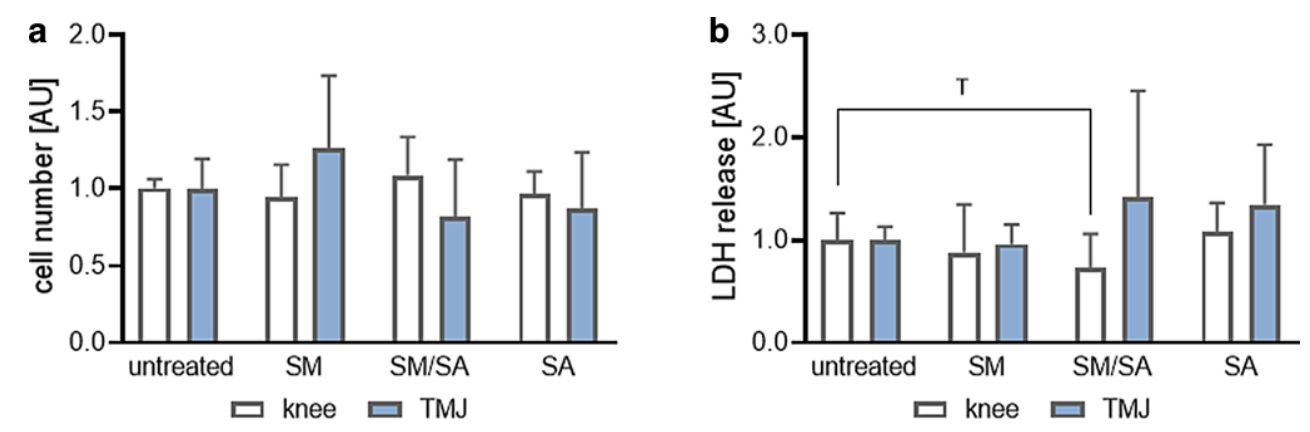

Fig. 3 Effects of dynamic stretching protocols on cell number $\left(n_{\text {knee }}=13, n_{\mathrm{TMJ}}=11 ; \mathbf{a}\right)$ and cytotoxicity $\left(n_{\mathrm{knee}}=13, n_{\mathrm{TMJ}}=12 ; \mathbf{b}\right)$ in synovial fibroblasts derived from knee and temporomandibular joint after different dynamic loading protocols. $A U$ arbitrary unit, $S M$ moderate, $S M / S A$ intermediate, $S A$ advanced. Statistics: Mixed-effects analysis with Geisser-Greenhouse correction followed by Holm-Sidak's multiple comparisons tests. ${ }^{\mathrm{T}} p<0.10$

Abb. 3 Auswirkungen der dynamischen Dehnungsprotokolle auf die Zellzahl $\left(n_{\mathrm{Knie}}=13, n_{\mathrm{TMJ}}=11 ; \mathbf{a}\right)$ und Zytotoxizität $\left(n_{\mathrm{Knie}}=13, n_{\mathrm{TMJ}}=12 ; \mathbf{b}\right)$ in synovialen Fibroblasten aus Knie- und Kiefergelenk nach unterschiedlichen dynamischen Belastungsprotokollen. $A U$ arbiträre Einheit, $S M$ moderat, $S M / S A$ gemischt, $S A$ anspruchsvoll. Statistik: Mixed-effects-Analyse mit Geisser-Greenhouse-Korrektur, gefolgt von Holm-Sidaks ,,multiple comparisons tests“. T $p<0,10$ 

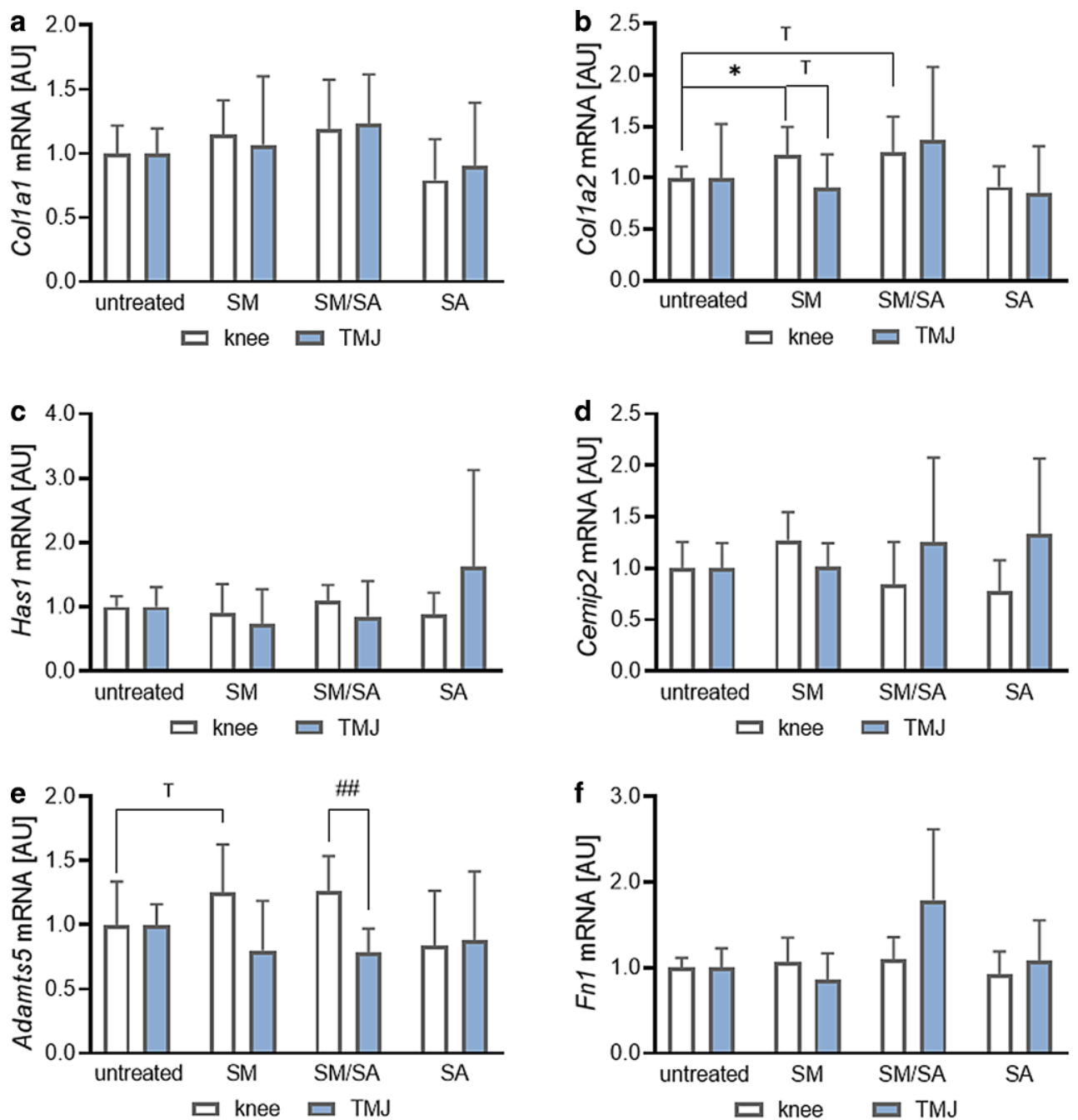

Fig. 4 Effects of dynamic stretching protocols on the genes Collal $\left(n_{\text {knee }}=13, n_{\mathrm{TMJ}}=10 ; \mathbf{a}\right)$, Colla $2\left(n_{\mathrm{knee}}=12, n_{\mathrm{TMJ}}=11 ; \mathbf{b}\right)$, Has $1\left(n_{\mathrm{knee}}=12\right.$, $\left.n_{\mathrm{TMJ}}=11 ; \mathbf{c}\right)$, Cemip2 $\left(n_{\mathrm{knee}}=8, n_{\mathrm{TMJ}}=10 ; \mathbf{d}\right)$, Adamts $5\left(n_{\mathrm{knee}}=8, n_{\mathrm{TMJ}}=6 ; \mathbf{e}\right)$ and $F n 1\left(n_{\mathrm{knee}}=8, n_{\mathrm{TMJ}}=6 ; \mathbf{f}\right)$ involved in extracellular-matrix remodelling in synovial fibroblasts derived from the knee and temporomandibular joint (TMJ). $A U$ arbitrary unit, $S M$ moderate, $S M / S A$ intermediate, $S A$ advanced. Statistics: Mixed-effects analysis with Geisser-Greenhouse correction followed by Holm-Sidak's multiple comparisons tests. $\mathrm{T}_{p}<0.10, * p<0.05$

Abb. 4 Effekte der dynamischen Dehnungsprotokolle auf die Gene Colla1 ( $\left.n_{\mathrm{Knie}}=13, n_{\mathrm{TMJ}}=10 ; \mathbf{a}\right)$, Colla2 $\left(n_{\mathrm{Knie}}=12\right.$, $\left.n_{\mathrm{TMJ}}=11 ; \mathbf{b}\right)$, Has1 $\left(n_{\mathrm{Knie}}=12, n_{\mathrm{TMJ}}=11 ; \mathbf{c}\right)$, Cemip $2\left(n_{\mathrm{Knie}}=8, n_{\mathrm{TMJ}}=10 ; \mathbf{d}\right)$, Adamts5 $\left(n_{\mathrm{Knie}}=8, n_{\mathrm{TMJ}}=6 ; \mathbf{e}\right)$ und $F n 1\left(n_{\mathrm{Knie}}=8, n_{\mathrm{TMJ}}=6 ; \mathbf{f}\right)$, die am Umbau der extrazellulären Matrix in synovialen Fibroblasten aus dem Knie- und dem Kiefergelenk (TMJ) beteiligt sind. $A U$ arbiträre Einheit, $S M$ moderat, $S M / S A$ gemischt, $S A$ anspruchsvoll. Statistik: Mixed-effects-Analyse mit Geisser-Greenhouse-Korrektur, gefolgt von Holm-Sidaks ,multiple comparisons tests“. 'T $p<0,10,{ }^{*} p<0,05$

SA: $p=0.8958 ;$ Fig. 4a). In contrast, collagen-1-alpha-2 (Colla2) gene expression was elevated in knee-derived synovial fibroblasts after moderate stretching (SM: $p=0.0352$; Fig. 4b). The mixed stretching protocol tended to increase Colla2 gene expression (SM/SA: $p=0.0762)$, while advanced stretching had no effect on Colla 2 gene expression in knee-derived synovial fibroblasts (SA: $p=0.3926$; Fig. 4b). Synovial fibroblasts derived from the TMJ failed to change gene expression of Colla2 upon any tested stretching protocol (SM: $p=0.9350$; SM/SA: $p=0.5057$; SA: $p=0.7993$; Fig. $4 b$ ). Therefore Colla2 tended to be differentially expressed after moderate stretching in knee- and TMJ-derived synovial fibroblasts (SM: $p=0.0629$ ). Hyaluronic acid is a polysaccharide synthesized by membrane-bound hyaluronic acid synthases (Has). Gene expression of Hasl was not affected by any tested stretching protocol in knee- (SM: $p=0.8696$; SM/SA: $p=0.5254$; SA: $p=0.6385$ ) and TMJ-derived synovial fibroblasts (SM: $p=0.4618$; SM/SA: $p=0.8149$; SA: $p=0.4153$; Fig. $4 \mathrm{c}$ ). Accordingly, gene expression of cell-migration-inducing hyaluronidase 2 (Cemip2), which cleaves extracellular high molecular weight hyaluronan, was not affected in knee- (SM: $p=0.1395$; SM/SA: $p=0.6544$; SA: $p=0.4198$ ) and TMJ-derived synovial fibroblasts by stretching (SM: 
$p=0.9982 ;$ SM/SA: $p=0.7111$; SA: $p=0.3437$; Fig. 4 d). Adamts 5 encodes for a member of a disintegrin and metalloproteinase protein family with thrombospondin motifs, which may be involved in osteoarthritis. In kneederived synovial fibroblasts, Adamts5 gene expression tended to be upregulated with moderate stretching (SM: $p=0.0765$ ), while mixed and advanced stretching did not impact Adamts5 gene expression (SM/SA: $p=0.4071$; SA: $p=0.8062$; Fig. 4e). In contrast, in TMJ-derived synovial fibroblasts Adamts5 gene expression was not affected by any stretching protocol tested (SM: $p=0.4844 ;$ SM/SA: $p=0.2580$; SA: $p=0.8414$ ), therefore resulting in significant differences between knee- and TMJ-derived synovial fibroblasts in Adamts 5 expression with the mixed stretching protocol (SM/SA: $p=0.0085$; Fig. $4 \mathrm{e})$. Last we analysed gene expression of Fibronectin-1 (Fnl). Fibronectin is a glycoprotein of the extracellular matrix and altered expression has been associated with a number of pathologies. Neither knee- (SM: $p=0.8086$; SM/SA: $p=0.6890$; SA: $p=0.8318$ ) nor TMJ-derived (SM: $p=0.6612$; SM/SA: $p=0.1876$; SA: $p=0.9337)$ synovial fibroblasts changed Fnl gene expression upon any tested stretching protocol with no differences depending on origin (Fig. 4f). From that data we conclude that mechanical loading impacted only knee-derived synovial fibroblasts on Colla 2 and Adamts 5 gene expression, while TMJ-derived synovial fibroblasts failed to react to mechanical loading.

\section{Impact on inflammatory gene expression}

Next, we investigated the expression of genes involved in inflammatory reactions. Interleukin-1-beta (Il1 $\beta$ ) is a highly effective cytokine promoting the increase of neutrophil granulocytes and interleukin-6. Surprisingly, we detected no changes in $I l 1 \beta$ gene expression with any stretching protocol in knee-derived synovial fibroblasts (SM: $p=0.7274$; SM/SA: $p=0.3952$; SA: $p=0.1835$ ). In TMJ-derived synovial fibroblasts moderate stretching even reduced $I l l \beta$ gene expression (SM: $p=0.0274$ ), while there were no changes with mixed or advanced stretching protocols (SM/SA: $p=0.7663$; SA: $p=0.9358$; Fig. 5a). With moderate stretching, we observed significant differences between synovial fibroblasts from the knee and the TMJ (SM: $p<0.001$ ), while the other tested protocols revealed no effects (SM/SA: $p=0.9484$; SA: $p=0.9484$; Fig. 5a). Interleukin-1 receptor antagonist (IL1RA) is an IL1 $\beta$ antagonist with inhibitory
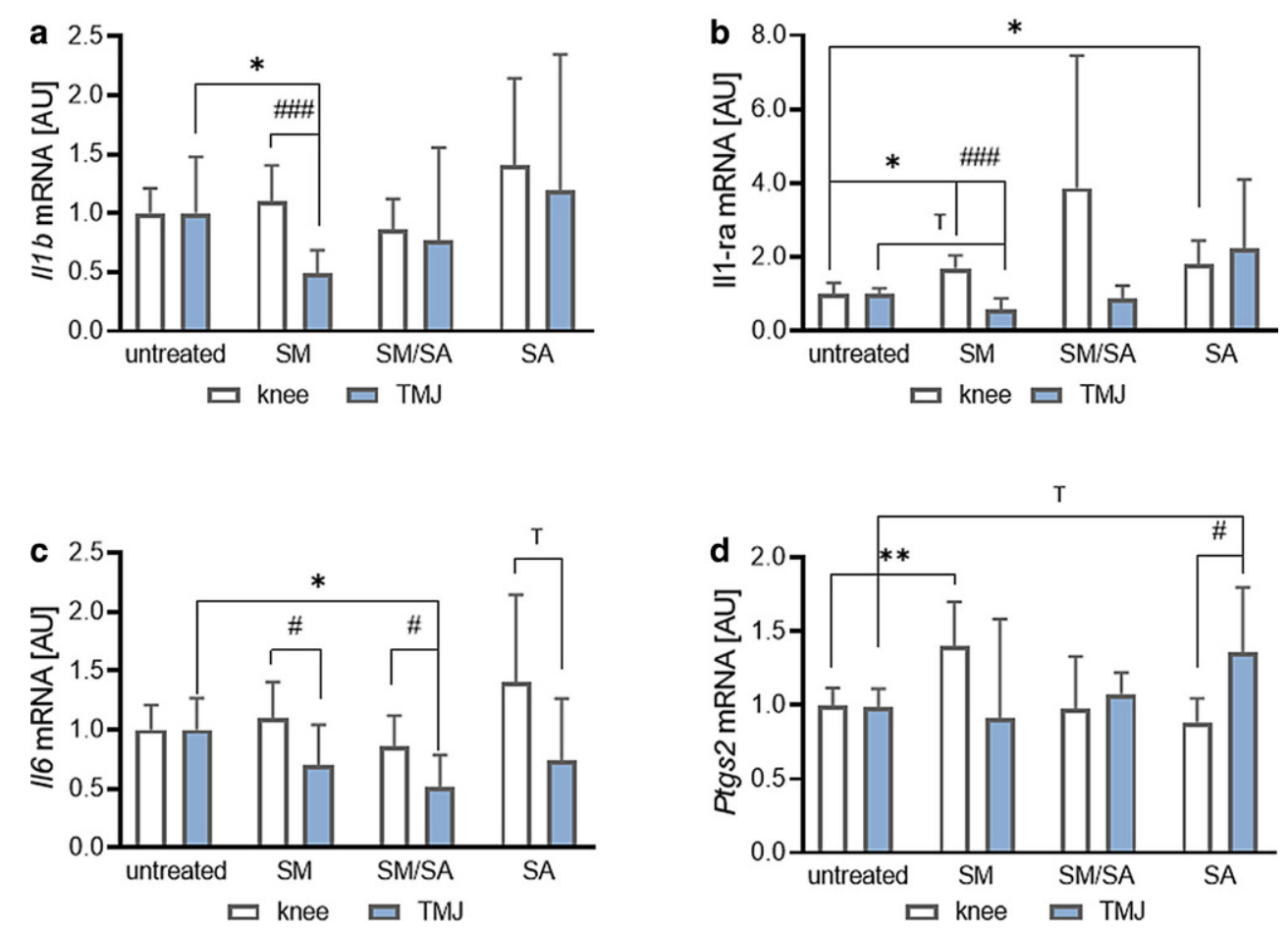

Fig. 5 Effects of dynamic stretching protocols on the inflammatory genes $I l l b\left(n_{\text {knee }}=12, n_{\mathrm{TMJ}}=10 ; \mathbf{a}\right), I l l-r a\left(n_{\mathrm{knee}}=8, n_{\mathrm{TMJ}}=7 ; \mathbf{b}\right), I l 6\left(n_{\mathrm{knee}}=12\right.$, $\left.n_{\mathrm{TMJ}}=8 ; \mathbf{c}\right)$ and Ptgs $2\left(n_{\mathrm{knee}}=12, n_{\mathrm{TMJ}}=11 ; \mathbf{d}\right)$ in synovial fibroblasts derived from the knee and temporomandibular joint (TMJ). $A U$ arbitrary unit, $S M$ moderate, $S M / S A$ intermediate, $S A$ advanced. Statistics: Mixed-effects analysis with Geisser-Greenhouse correction followed by Holm-Sidak's multiple comparisons tests. ${ }^{\mathrm{T}} p<0.10,{ }^{*}, \# p<0.05, * *, \# \#<0.01, * * *, \# \# p<0.001$

Abb. 5 Auswirkungen von dynamischen Dehnungsprotokollen auf die Entzündungsgene $\operatorname{Ill} b\left(n_{\mathrm{Knie}}=12, n_{\mathrm{TMJ}}=10 ; \mathbf{a}\right), \operatorname{Ill} \mathrm{ra}\left(n_{\mathrm{Knie}}=8, n_{\mathrm{TMJ}}=7 ; \mathbf{b}\right)$, Il6 $\left(n_{\mathrm{Knie}}=12, n_{\mathrm{TMJ}}=8 ; \mathbf{c}\right)$ und Ptgs $2\left(n_{\mathrm{Knie}}=12, n_{\mathrm{TMJ}}=11 ; \mathbf{d}\right)$ in synovialen Fibroblasten aus dem Knie- und dem Kiefergelenk (TMJ). $A U$ arbiträre Einheit, $S M$ moderat, $S M / S A$ gemischt, $S A$ anspruchsvoll. Statistik: Mixed-effects-Analyse mit Geisser-Greenhouse-Korrektur, gefolgt von HolmSidaks ,,multiple comparisons tests“. T $p<0,10,{ }^{*}, \# p<0,05, * *, \# \# p<0,01, * * *, \# \# p<0,001$ 
attributes to inflammation. As response to inflammation, IL1RA will be upregulated in order to dampen IL1 $\beta$-mediated signalling $[4,58]$. Both moderate (SM: $p=0.0104)$ and advanced stretching (SA: $p=0.0190)$ increased Ill-ra gene expression in knee-derived synovial fibroblasts, while moderate stretching had no effect (SM: $p=0.1330$; Fig. 5b). In contrast to knee-derived synovial fibroblasts, cells from TMJ origin tended to reduce Il1ra expression with moderate dynamic stretching $(p=0.0982)$, while mixed (SM/SA: $p=0.7778)$ or advanced stretching (SA: $p=0.3892)$ had no effects. Moderate stretching revealed a significant difference between cells derived from the knee and the TMJ ( $p<0.001$; Fig. 5b). IL6 signalling is regulated by IL1 $\beta$. Hence, we detected no changes in $I l 6$ gene expression in knee-derived synovial fibroblasts (SM: $p=0.7274$; SM/SA: $p=0.3952$; SA: $p=0.1835$; Fig. 5c). In accordance, neither moderate (SM: $p=0.1921)$ nor advanced (SA: $p=0.5204$ ) stretching affected Il6 gene expression in TMJ-derived fibroblasts. Mixed stretching, however, resulted in a significant downregulation of $I l 6$ ( $p=0.0302$; Fig. 5c), indicating an anti-inflammatory reaction of TMJ-derived synovial fibroblasts. We observed differences in Il6 gene expression in synovial fibroblasts depending on their origin after moderate (SM: $p=0.0382)$ and mixed stretching (SM/SA: $p=0.0303$ ), while advanced stretching (SA: $p=0.0525)$ tended to downregulate Il6 expression in the TMJ- compared to knee-derived fibroblasts (Fig. 5c). Prostaglandin endoperoxidase synthase 2 (PTGS2) is responsible for prostaglandin synthesis from arachidonic acid. In kneederived synovial fibroblasts moderate stretching increased Ptgs2 gene expression ( $p=0.0032)$, while mixed (SM/SA: $p=0.9925)$ or advanced stretching (SA: $p=0.1124$ ) had no effect (Fig. 5d). In contrast, advanced stretching tended to increase Ptgs 2 gene expression $(p=0.0998)$ in TMJ-derived fibroblasts with no effects of moderate (SM: $p=0.9680$ ) or mixed stretching (SM/SA: $p=0.3773)$. Gene expression of Ptgs 2 upon advanced stretching was dependent on the origin of synovial fibroblasts ( $p=0.0337$; Fig. $5 \mathrm{~d}$ ). These data indicate that knee- and TMJ-derived synovial fibroblasts strongly differ in the gene expression profile of inflammatory genes in reaction to dynamic stretching protocols.

\section{Impact on bone-remodelling gene expression}

The expression ratio of receptor activator of $\mathrm{NF}-\kappa \mathrm{B}$ ligand (RANKL) to its decoy receptor osteoprotegerin (OPG) is a driving force for osteoclastogenesis [38]. In knee-derived synovial fibroblasts, none of the dynamic stretching protocols influenced $O p g$ gene expression (SM: $p=0.2004$; SM/SA: $p=0.7957$; SA: $p=0.2319$; Fig. 6a). Similarly, only mixed stretching tended to increase (SM/SA: $p=0.0970)$ Opg gene expression in TMJ-derived synovial fibroblasts with no effects of moderate (SM: $p=0.1630$ ) or advanced stretching (SA: $p=0.9838)$. Opg tended to be differentially expressed in fibroblasts from the knee and the TMJ after mixed dynamic stretching (SM/SA: $p=0.0938$; Fig. 6a). Rankl gene expression was elevated in knee-derived synovial fibroblasts after moderate stretching (SM: $p=0.0104)$, while neither mixed (SM/SA: $p=0.9933$ ) nor advanced stretching (SA: $p=0.9966)$ affected Rankl gene expression (Fig. 6b). In contrast, TMJ-derived synovial fibroblasts did not change Rankl gene expression after any dynamic stretching protocol (SM: $p=0.1228$; SM/SA: $p=0.2702$; SA: $p=0.9433$; Fig. 6b). Compared to knee-derived synovial fibroblasts, TMJ-derived cells reduced Rankl gene expression upon moderate stretching (SM: $p<0.001$ ). Rankl/Opg ratio tended to be increased upon moderate loading (SM: $p=0.0791$ ), while advanced stretching reduced the Rankl/Opg ratio significantly (SA: $p=0.0026$; Fig. 6c) in knee synovial fibroblasts. In contrast, we observed a significant downregulation of the Rankl/Opg ratio in TMJ synovial fibroblasts with moderate (SM: $p=0.0164$ ) and mixed stretching (SM/SA: $p=0.0017)$, while advanced stretching had no effect (SA: $p=0.8971$; Fig. 6c). Thus, differences depending on synovial fibroblast origin seem to exist after moderate (SM: $p<0.001)$ and mixed (SM/SA: $p=0.0031$ ) stretching (Fig. 6c), indicating different reactions to dynamic stretching.

\section{Discussion}

Studies analysing the structural development of joints proved that it is difficult to define distinct determining factors of tissues and structures. Joint formation seems like an event of coincidence, guided by delicate processes of limb patterning, embryonic movement and extracellular matrix composition, while the right dose of local signalling events support the process of joint cavity formation [28, 35]. To further complicate this process, each joint needs its own factors of determination and develops from distinct germ layers, while the composition of structural components almost maintains the same. Focusing on already developed joints, we analysed synovial fibroblasts descended from two different layers to gain insight into osteoarthritis development and progression of the knee and temporomandibular joint (TMJ): synovial fibroblasts from the TMJ, descending from the ectoderm, and synovial fibroblasts from the knee joint, descending from the mesoderm. Although both synovial fibroblast populations are located in their corresponding synovial tissue and perform similar tasks in the upkeeping of joint homeostasis [30], we observed differences in their response to mechanical stress. Extracellular matrix remodelling processes play a role during embryogenic development, but also in the pathogenesis of joint 

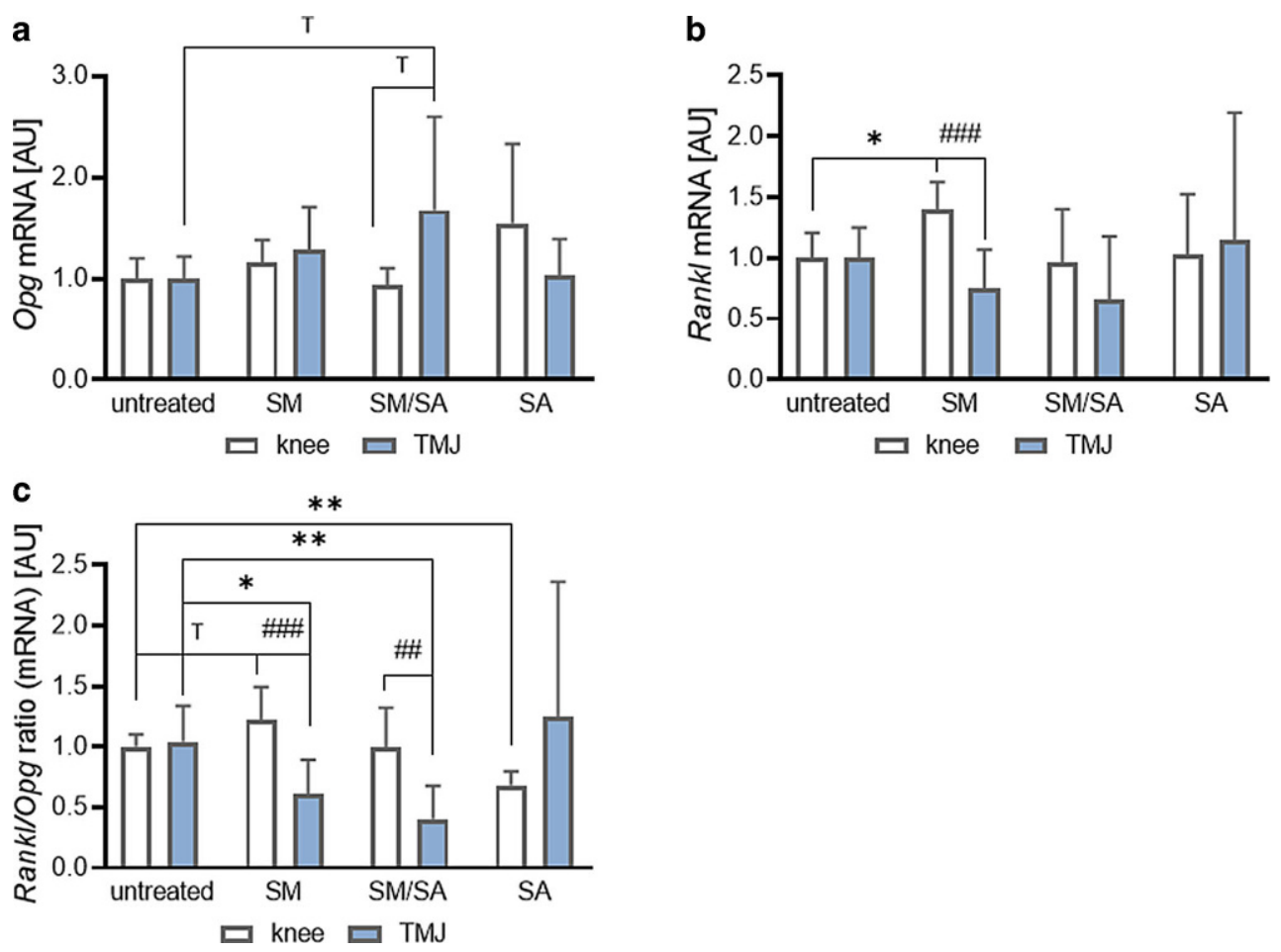

Fig. 6 Effects of dynamic stretching protocols on the bone remodelling genes $O p g\left(n_{\mathrm{knee}}=7, n_{\mathrm{TMJ}}=11 ; \mathbf{a}\right)$ and $\operatorname{Rankl}\left(n_{\mathrm{knee}}=7, n_{\mathrm{TMJ}}=11 ; \mathbf{b}\right)$ and the Rankl/Opg ratio ( $\left.n_{\mathrm{knee}}=7, n_{\mathrm{TMJ}}=11 ; \mathbf{c}\right)$ in synovial fibroblasts derived from the knee and temporomandibular joint (TMJ). $A U$ arbitrary unit, $S M$ moderate, $S M / S A$ intermediate, $S A$ advanced. Statistics: Mixed-effects analysis with Geisser-Greenhouse correction followed by Holm-Sidak's

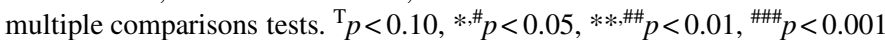

Abb. 6 Auswirkungen von dynamischen Dehnungsprotokollen auf die Knochenumbaugene $O p g\left(n_{\mathrm{Knie}}=7, n_{\mathrm{TMJ}}=11 ; \mathbf{a}\right)$ und $R a n k l\left(n_{\mathrm{Knie}}=7\right.$, $\left.n_{\mathrm{TMJ}}=11 ; \mathbf{b}\right)$ sowie das Rankl/Opg-Verhältnis $\left(n_{\mathrm{Knie}}=7, n_{\mathrm{TMJ}}=11 ; \mathbf{c}\right)$ in synovialen Fibroblasten aus dem Knie- und dem Kiefergelenk (TMJ). $A U$ arbiträre Einheit, $S M$ moderat, $S M / S A$ gemischt, $S A$ anspruchsvoll. Statistik: Mixed-effects-Analyse mit Geisser-Greenhouse-Korrektur, gefolgt

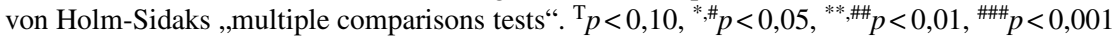

disorders such as osteoarthritis (OA), which also affects the TMJ, and corresponding tissue infiltration [57].

Synovitis is an example of an arthritic event of tissue infiltration, as the synovial membrane experiences synovial lining hyperplasia, infiltration of macrophages and lymphocytes and neoangiogenesis, while the release of proteolytic factors favours cartilage breakdown $[8,33,59]$ (for further information see review: [48]). While developing synovitis, synovial tissue experiences a pathological fibrotic change (synovial fibrosis), characterised by clinical symptoms of pain and stiffness, favoured by excessive extracellular matrix (ECM) deposition and mediated by synovial fibroblasts $[25,32,45]$.

A factor regulating OA-induced cartilage degeneration is ADAMTS (a disintegrin and metalloproteinase with thrombospondin motif), capable of cleaving the major cartilage proteoglycan aggrecan [24, 40]. Also high levels of fragmented fibronectin indicate arthritic changes [5, 12]. Furthermore, a change of collagen content occurs during OA pathogenesis [39], while small fragments of hyaluronan support inflammatory processes [53]. In the context of ECM composition and remodelling, the markers tested in this study showed no different expression pattern between syn- ovial fibroblasts derived from the knee compared to those derived from the TMJ. However, for certain types of mechanical strain, they differed in gene expression of Colla2 and Adamts5.

Also factors of inflammation experienced a differential expression, depending on the origin of the synovial fibroblasts. A study analysing topographically differing synovial fibroblast populations found distinct gene expression patterns for genes involved in limb patterning, chemotaxis, cell-cell interactions and inflammation [20]. Although the synovial fibroblasts tested were derived from the knee joint, hand and shoulder, we also were able to see differences in inflammatory gene expression pattern between synovial fibroblasts derived from the knee and the TMJ. The expression of Ptgs2, which is involved in prostaglandin E2 synthesis, supports cell proliferation events, as well as angiogenesis, apoptosis and immunoregulating processes, while being induced by cytokines, growth factors and inflammation [47, 56]. A PTGS2-inducing cytokine is IL-1 $\beta$, acting via the ERK pathway [36]. Apart from IL-1 $\beta$, also IL-6 plays an arthritis- and inflammation-mediating role $[11,23]$. In order to regulate initiated inflammatory events, IL- 6 and IL$1 \beta$ stimulate the expression of Interleukin 1 receptor antago- 
nist (IL1RA) [21]. By binding to interleukin 1 receptors, the endogenous negative-feedback regulator IL-1RA is able to reduce inflammation-induced signalling, while experiencing acute-phase protein attributes [21]. In our study, we observed an altered gene expression depending on origin of cells and exhaustion due to mechanical strain for all four inflammation-associated markers. While Il-1 ra experienced an upregulation in gene expression under moderate stretching (SM) and advanced stretching (SA) conditions in the case of synovial fibroblasts derived from the knee, synovial fibroblasts derived from TMJ only experienced a trend in downregulating gene expression under low exhaustive conditions. This observation led to a clearly differing gene expression pattern based on synovial fibroblast descendance, which only was present in the moderate stretching condition. As $I L-1 \mathrm{ra}$ acts responding to increased proinflammatory cytokine expression in order to regulate inflammatory events, we expected a similar gene expression for $I l l \beta$ and Il6. While only $I l 1 \beta$ gene expression was diminished for synovial fibroblasts derived from the TMJ during low exhaustive conditions, this was the only condition confirming a coherence between $I l l \beta$ and $I l-1 \mathrm{ra}$ gene expression.

A critical element of OA pathogenesis is bone resorption, mediating destructive and irreversible affliction, while increasing pain and decreasing mobility. The process of bone resorption is mediated by osteoclast formation and activation induced by receptor activator of nuclear factor $\kappa B$ ligand (RANKL). While the binding of RANKL to the RANK receptor induces bone resorption processes, the decoy receptor osteoprotegerin (OPG) has a higher binding affinity to RANKL and prevents RANKL-mediated signalling. Synovial fibroblasts act as principal RANKL-expressing cells, therefore playing a major role in bone destruction during arthritis [17]. In our experimental set-up, we only observed increased Rankl expression for low exhaustive conditions in synovial fibroblasts derived from the knee joint, while corresponding Opg expression was not altered. Therefore, $O p g$ expression was only increased by mixed stretching conditions (SM/SA) for synovial fibroblasts derived from the TMJ. By assessing the Rankl/Opg ratio, insights into potential osteoclast activation and formation are obtained with a value higher than 1 indicating an imbalance in favour of Rankl activating osteoclast formation and a value smaller than 1 favouring $O p g$, thus diminishing osteoclast formation. For synovial fibroblasts derived from the knee joint, low exhaustive conditions favoured, while exhaustive conditions diminished the Rankl/Opg ratio. In contrast, low and intermediate exhaustive conditions had reducing effects on the Rankl/Opg ratio in synovial fibroblasts from the TMJ.

For all tested attributes (inflammation, ECM remodelling, bone remodelling), we saw similarities in gene expression behaviour and distinctly differing gene expres- sion patterns between synovial fibroblast populations. As we compared the effect of mechanical strain to unstressed cells, we did not analyse the transcriptome of synovial fibroblasts originating from diverse tissues. However, we were able to see a distinctly different activation of gene expression between the tested cell populations. This shows that mechanical stress has a different impact on synovial fibroblasts and that synovial fibroblasts derived from different joints diverge in osteoclastogenesis and inflammatory activation. During embryonic development HOX genes (homeobox genes) define the head-tail axis and limb patterning by segmental expression and DNA transcription activation. However, when analysing gene expression in synovial fibroblasts of adult donors, distinct HOX gene expression is maintained corresponding to the anatomical origin [20]. Based on the differing gene expression of synovial fibroblast populations, HOX gene expression may influence inflammation via the NF- $\mathrm{KB}$ pathway [43, 52], while tissue-specific expression patterns of cell-cell interaction and inflammation [20] are boosted by mechanical strain. Our findings show that OA pathogenesis is a complex process with risk factors such as mechanical overuse vary in biasing OA dependent on the joint of origin.

\section{Conclusions}

The responses in gene expression due to different dynamic stretching protocols are strongly dependent on the origin of synovial fibroblasts. Synovial fibroblasts derived from the temporomandibular joint reduce the Rankl/Opg gene expression ratio after moderate and mixed dynamic stretching, while, in contrast to genes involved in inflammation or bone remodelling, expression profiles of genes involved in extracellular matrix remodelling are mostly not affected by dynamic stretching independent of their origin. Our data indicate that risk factors for the development and progression of osteoarthritis such as mechanical overuse have a different pathological impact in the temporomandibular joint compared to the knee joint.

Supplementary Information The online version of this article (https:// doi.org/10.1007/s00056-021-00309-y) contains supplementary material, which is available to authorized users.

Acknowledgements The authors thank MTA Eva Zaglauer and Anna Huber for their technical support. The authors want to thank the German Orthodontic Society DGKFO and the German Research Foundation DFG for the funding of this study.

Funding This study was funded by the German Orthodontic Society (grant Kirschneck 2020) and partly funded by a DFG grant (GR1301/19-1) as part of the research consortium FOR2407/1 assigned to $\mathrm{S}$. Grässel. 
Funding Open Access funding enabled and organized by Projekt DEAL.

\section{Declarations}

Conflict of interest U. Nazet, P. Neubert, V. Schatz, S. Grässel, P. Proff, J. Jantsch, A. Schröder and C. Kirschneck declare that they have no competing interests.

Ethical standards All procedures performed in studies involving animal tissue were in accordance with the ethical standards of the institutional and/or national research committee. Animals were treated conforming to national and institutional regulations.

Open Access This article is licensed under a Creative Commons Attribution 4.0 International License, which permits use, sharing, adaptation, distribution and reproduction in any medium or format, as long as you give appropriate credit to the original author(s) and the source, provide a link to the Creative Commons licence, and indicate if changes were made. The images or other third party material in this article are included in the article's Creative Commons licence, unless indicated otherwise in a credit line to the material. If material is not included in the article's Creative Commons licence and your intended use is not permitted by statutory regulation or exceeds the permitted use, you will need to obtain permission directly from the copyright holder. To view a copy of this licence, visit http://creativecommons.org/licenses/by/4. $0 \%$.

\section{References}

1. Alomar X, Medrano J, Cabratosa J, Clavero JA, Lorente M, Serra I, Monill JM, Salvador A (2007) Anatomy of the temporomandibular joint. Semin Ultrasound CT MR 28:170-183. https://doi.org/10. 1053/j.sult.2007.02.002

2. Angelova A, Ilieva EM (2016) Effectiveness of high intensity laser therapy for reduction of pain in knee osteoarthritis. Pain Res Manag. https://doi.org/10.1155/2016/9163618

3. Armaka M, Gkretsi V, Kontoyiannis D, Kollias G (2009) A standardized protocol for the isolation and culture of normal and arthritogenic murine synovial fibroblasts. Nat Protoc. https://doi.org/10. 1038/nprot.2009.102

4. Attur M, Zhou H, Samuels J, Krasnokutsky S, Yau M, Scher JU, Doherty $M$ et al (2020) Interleukin 1 receptor antagonist (IL1RN) gene variants predict radiographic severity of knee osteoarthritis and risk of incident disease. Ann Rheum Dis 79:400-407. https:// doi.org/10.1136/annrheumdis-2019-216055

5. Barilla ML, Carsons SE (2000) Fibronectin fragments and their role in inflammatory arthritis. Semin Arthritis Rheum 29:252-265. https://doi.org/10.1016/s0049-0172(00)80012-8

6. Belluzzi E, Stocco E, Pozzuoli A, Granzotto M, Porzionato A, Vettor R, de Caro R et al (2019) Contribution of Infrapatellar fat pad and synovial membrane to knee osteoarthritis pain. Biomed Res Int 2019:6390182. https://doi.org/10.1155/2019/6390182

7. Bhattaram P, Chandrasekharan U (2017) The joint synovium: a critical determinant of articular cartilage fate in inflammatory joint diseases. Semin Cell Dev Biol 62:86-93. https://doi.org/10.1016/ j.semcdb.2016.05.009

8. Blom AB, van Lent PL, Libregts S, Holthuysen AE, van der Kraan PM, van Rooijen N, van den Berg WB (2007) Crucial role of macrophages in matrix metalloproteinase-mediated cartilage destruction during experimental osteoarthritis: involvement of matrix metalloproteinase 3. Arthritis Rheum 56:147-157. https://doi.org/ 10.1002/art.22337
9. Brosseau L, Welch V, Wells G, Tugwell P, de Bie R, Gam A, Harman $\mathrm{K}$ et al (2000) Low level laser therapy for osteoarthritis and rheumatoid arthritis: a metaanalysis. J Rheumatol 27:1961-1969

10. Bustin SA, Benes V, Garson JA, Hellemans J, Huggett J, Kubista M, Mueller R et al (2009) The MIQE guidelines: minimum information for publication of quantitative real-time PCR experiments. Clin Chem 55:611-622. https://doi.org/10.1373/clinchem.2008.112797

11. Cai H, Sun H-J, Wang Y-H, Zhang Z (2015) Relationships of common polymorphisms in IL-6, IL-1A, and IL-1B genes with susceptibility to osteoarthritis: a meta-analysis. Clin Rheumatol 34:1443-1453. https://doi.org/10.1007/s10067-014-2708-x

12. Carsons S, Mosesson MW, Diamond HS (1981) Detection and quantitation of fibronectin in synovial fluid from patients with rheumatic disease. Arthritis Rheum 24:1261-1267

13. Chang SH, Mori D, Kobayashi H, Mori Y, Nakamoto H, Okada K, Taniguchi $\mathrm{Y}$ et al (2019) Excessive mechanical loading promotes osteoarthritis through the gremlin-1-NF- $\mathrm{KB}$ pathway. Nat Commun 10:1442. https://doi.org/10.1038/s41467-019-09491-5

14. Clark RB, Schmidt TA, Sachse FB, Boyle D, Firestein GS, Giles WR (2017) Cellular electrophysiological principles that modulate secretion from synovial fibroblasts. J Physiol 595:635-645. https://doi.org/10.1113/JP270209

15. Cook SD, Salkeld SL, Patron LP, Doughty ES, Jones DG (2008) The effect of low-intensity pulsed ultrasound on autologous osteochondral plugs in a canine model. Am J Sports Med 36:1733-1741. https://doi.org/10.1177/0363546508316766

16. Crossman J, Alzaheri N, Abdallah M-N, Tamimi F, Flood P, Alhadainy $\mathrm{H}$, El-Bialy $\mathrm{T}$ (2019) Low intensity pulsed ultrasound increases mandibular height and Col-II and VEGF expression in arthritic mice. Arch Oral Biol 104:112-118. https://doi.org/10. 1016/j.archoralbio.2019.05.032

17. Danks L, Komatsu N, Guerrini MM, Sawa S, Armaka M, Kollias G, Nakashima T, Takayanagi H (2016) RANKL expressed on synovial fibroblasts is primarily responsible for bone erosions during joint inflammation. Ann Rheum Dis 75:1187-1195. https://doi.org/10. 1136/annrheumdis-2014-207137

18. Chen D, Shen J, Zhao W, Wang T, Han L, Hamilton JL, Im H-J (2017) Osteoarthritis: toward a comprehensive understanding of pathological mechanism. Bone Res 5:16044. https://doi.org/10. 1038/boneres.2016.44

19. Felson DT, Niu J, Neogi T, Goggins J, Nevitt MC, Roemer F, Torner J et al (2016) Synovitis and the risk of knee osteoarthritis: the MOST Study. Osteoarthr Cartil 24:458-464. https://doi.org/10. 1016/j.joca.2015.09.013

20. Frank-Bertoncelj M, Trenkmann M, Klein K, Karouzakis E, Rehrauer H, Bratus A, Kolling C et al (2017) Epigeneticallydriven anatomical diversity of synovial fibroblasts guides jointspecific fibroblast functions. Nat Commun 8:14852. https://doi.org/ $10.1038 /$ ncomms 14852

21. Gabay C, Smith MF, Eidlen D, Arend WP (1997) Interleukin 1 receptor antagonist (IL-1Ra) is an acute-phase protein. J Clin Invest 99:2930-2940. https://doi.org/10.1172/JCI1 19488

22. Gauer RL, Semidey MJ (2015) Diagnosis and treatment of temporomandibular disorders. Am Fam Physician 91:378-386

23. Gauldie J, Richards C, Harnish D, Lansdorp P, Baumann H (1987) Interferon beta $2 / \mathrm{B}$-cell stimulatory factor type 2 shares identity with monocyte-derived hepatocyte-stimulating factor and regulates the major acute phase protein response in liver cells. Proc Natl Acad Sci U S A 84:7251-7255. https://doi.org/10.1073/pnas.84.20.7251

24. Glasson SS, Askew R, Sheppard B, Carito B, Blanchet T, Ma H-L, Flannery CR et al (2005) Deletion of active ADAMTS5 prevents cartilage degradation in a murine model of osteoarthritis. Nature 434:644-648. https://doi.org/10.1038/nature03369

25. Györfi AH, Matei A-E, Distler JH (2018) Targeting TGF- $\beta$ signaling for the treatment of fibrosis. Matrix Biol 68-69:8-27. https:// doi.org/10.1016/j.matbio.2017.12.016 
26. Hardy RS, Hülso C, Liu Y, Gasparini SJ, Fong-Yee C, Tu J, Stoner S et al (2013) Characterisation of fibroblast-like synoviocytes from a murine model of joint inflammation. Arthritis Res Ther 15:R24. https://doi.org/10.1186/ar4158

27. Herrero-Beaumont G, Roman-Blas JA, Castañeda S, Jimenez SA (2009) Primary osteoarthritis no longer primary: three subsets with distinct etiological, clinical, and therapeutic characteristics. Semin Arthritis Rheum 39:71-80. https://doi.org/10.1016/j.semarthrit. 2009.03.006

28. Hinton RJ (2014) Genes that regulate morphogenesis and growth of the temporomandibular joint: a review. Dev Dyn 243:864-874. https://doi.org/10.1002/dvdy.24130

29. Hoffer A (1959) Treatment of arthritis by nicotinic acid and nicotinamide. Can Med Assoc J 81:235-238

30. Hui AY, McCarty WJ, Masuda K, Firestein GS, Sah RL (2012) A systems biology approach to synovial joint lubrication in health, injury, and disease. Wiley Interdiscip Rev Syst Biol Med 4:15-37. https://doi.org/10.1002/wsbm.157

31. Kim E-D, Won YH, Park S-H, Seo J-H, Kim D-S, Ko M-H, Kim G-W (2019) Efficacy and Safety of a Stimulator Using LowIntensity Pulsed Ultrasound Combined with Transcutaneous Electrical Nerve Stimulation in Patients with Painful Knee Osteoarthritis. Pain Res Manag. https://doi.org/10.1155/2019/7964897

32. Kim KK, Sheppard D, Chapman HA (2018) TGF- $\beta 1$ signaling and tissue fibrosis. Cold Spring Harb Perspect Biol. https://doi.org/10. 1101/cshperspect.a022293

33. Krenn V, Perino G, Rüther W, Krenn VT, Huber M, Hügle T, Najm A et al (2017) 15 years of the histopathological synovitis score, further development and review: a diagnostic score for rheumatology and orthopaedics. Pathol Res Pract 213:874-881. https://doi.org/10.1016/j.prp.2017.05.005

34. Kubiak M, Ditzel M (2016) A joint less ordinary: intriguing roles for hedgehog signalling in the development of the temporomandibular synovial joint. J Dev Biol. https://doi.org/10.3390/ jdb4030025

35. Lamb KJ, Lewthwaite JC, Bastow ER, Pitsillides AA (2003) Defining boundaries during joint cavity formation: going out on a limb. Int J Exp Pathol 84:55-67. https://doi.org/10.1046/j.1365-2613. 2003.00338.x

36. Laporte JD, Moore PE, Abraham JH, Maksym GN, Fabry B, Panettieri RA, Shore SA (1999) Role of ERK MAP kinases in responses of cultured human airway smooth muscle cells to IL-1beta. Am J Physiol 277:L943-L951. https://doi.org/10.1152/ajplung.1999. 277.5.L943

37. Lohberger B, Kaltenegger H, Weigl L, Mann A, Kullich W, Stuendl N, Leithner A, Steinecker-Frohnwieser B (2019) Mechanical exposure and diacerein treatment modulates integrinFAK-MAPKs mechanotransduction in human osteoarthritis chondrocytes. Cell Signal 56:23-30. https://doi.org/10.1016/j.cellsig. 2018.12.010

38. Lorenzo J (2017) The many ways of osteoclast activation. J Clin Invest 127:2530-2532. https://doi.org/10.1172/JCI94606

39. Miosge N, Hartmann M, Maelicke C, Herken R (2004) Expression of collagen type I and type II in consecutive stages of human osteoarthritis. Histochem Cell Biol 122:229-236. https://doi.org/10. 1007/s00418-004-0697-6

40. Morgan RE, Clegg PD, Hunt JA, Innes JF, Tew SR (2018) Interaction with macrophages attenuates equine fibroblast-like synoviocyte ADAMTS5 (aggrecanase-2) gene expression following inflammatory stimulation. J Orthop Res. https://doi.org/10.1002/jor.23891

41. Nazet U, Grässel S, Jantsch J, Proff P, Schröder A, Kirschneck C (2020) Early OA stage like response occurs after dynamic stretching of human synovial fibroblasts. Int J Mol Sci 21:3874. https:// doi.org/10.3390/ijms21113874

42. Ntougkos E, Chouvardas P, Roumelioti F, Ospelt C, Frank-Bertoncelj M, Filer A, Buckley CD et al (2017) Genomic responses of mouse synovial fibroblasts during tumor necrosis factor-driven arthritogenesis greatly mimic those in human rheumatoid arthritis. Arthritis Rheumatol 69:1588-1600. https://doi.org/10.1002/art. 40128

43. Pai P, Sukumar S (2020) HOX genes and the NF- $\kappa B$ pathway: a convergence of developmental biology, inflammation and cancer biology. Biochim Biophys Acta Rev Cancer. https://doi.org/10.1016/ j.bbcan.2020.188450

44. Paolillo FR, Paolillo AR, João JP, Frascá D, Duchêne M, João HA, Bagnato VS (2018) Ultrasound plus low-level laser therapy for knee osteoarthritis rehabilitation: a randomized, placebo-controlled trial. Rheumatol Int 38:785-793. https://doi.org/10.1007/s00296018-4000-x

45. Remst DF, Blaney Davidson EN, Vitters EL, Blom AB, Stoop R, Snabel JM, Bank RA et al (2013) Osteoarthritis-related fibrosis is associated with both elevated pyridinoline cross-link formation and lysyl hydroxylase $2 b$ expression. Osteoarthr Cartil 21:157-164. https://doi.org/10.1016/j.joca .2012.10.002

46. Rothenberg JB, Jayaram P, Naqvi U, Gober J, Malanga GA (2017) The role of low-intensity pulsed ultrasound on cartilage healing in knee osteoarthritis: a review. PM R 9:1268-1277. https://doi.org/ 10.1016/j.pmrj.2017.05.008

47. Rumzhum NN, Ammit AJ (2016) Cyclooxygenase 2: its regulation, role and impact in airway inflammation. Clin Exp Allergy 46:397-410. https://doi.org/10.1111/cea.12697

48. Scanzello CR, Goldring SR (2012) The role of synovitis in osteoarthritis pathogenesis. Bone 51:249-257. https://doi.org/10. 1016/j.bone.2012.02.012

49. Schröder A, Gubernator J, Nazet U, Spanier G, Jantsch J, Proff P, Kirschneck C (2020) Auswirkungen von Natriumchlorid auf das Genexpressionsprofil parodontaler Ligamentfibroblasten bei Dehnung. J Orofac Orthop 81:360-370. https://doi.org/10.1007/ s00056-020-00232-8

50. Schröder A, Nazet U, Neubert P, Jantsch J, Spanier G, Proff P, Kirschneck C (2019) Sodium-chloride-induced effects on the expression profile of human periodontal ligament fibroblasts with focus on simulated orthodontic tooth movement. Eur J Oral Sci 127:386-395. https://doi.org/10.1111/eos. 12643

51. Suzuki A, Iwata J (2016) Mouse genetic models for temporomandibular joint development and disorders. Oral Dis 22:33-38. https://doi.org/10.1111/odi.12353

52. Taminiau A, Draime A, Tys J, Lambert B, Vandeputte J, Nguyen N, Renard $\mathrm{P}$ et al (2016) HOXA1 binds RBCK1/HOIL-1 and TRAF2 and modulates the TNF/NF- $\mathrm{KB}$ pathway in a transcription-independent manner. Nucleic Acids Res 44:7331-7349. https://doi.org/10. 1093/nar/gkw606

53. Tolg C, Telmer P, Turley E (2014) Specific sizes of hyaluronan oligosaccharides stimulate fibroblast migration and excisional wound repair. Plos One. https://doi.org/10.1371/journal.pone. 0088479

54. Valencia X, Higgins JM, Kiener HP, Lee DM, Podrebarac TA, Dascher CC, Watts GF et al (2004) Cadherin-11 provides specific cellular adhesion between fibroblast-like synoviocytes. J Exp Med 200:1673-1679. https://doi.org/10.1084/jem.20041545

55. van der Kraan PM, van den Berg WB (2012) Chondrocyte hypertrophy and osteoarthritis: role in initiation and progression of cartilage degeneration? Osteoarthr Cartil 20:223-232. https://doi.org/ 10.1016/j.joca.2011.12.003

56. Wang W, Wang J (2018) Toll-Like Receptor 4 (TLR4)/ Cyclooxygenase-2 (COX-2) regulates prostate cancer cell proliferation, migration, and invasion by NF- $\mathrm{BB}$ activation. Med Sci Monit 24:5588-5597. https://doi.org/10.12659/MSM.906857

57. Wang X, Khalil RA (2018) Matrix metalloproteinases, vascular remodeling, and vascular disease. Adv Pharmacol 81:241-330. https://doi.org/10.1016/bs.apha.2017.08.002 
58. Wu T-C, Xu K, Martinek J, Young RR, Banchereau R, George J, Turner J et al (2018) IL1 receptor antagonist controls transcriptional signature of inflammation in patients with metastatic breast cancer. Cancer Res 78:5243-5258. https://doi.org/10.1158/0008-5472. CAN-18-0413

59. Zhang L, Xing R, Huang Z, Zhang N, Li X, Wang P (2019) Inhibition of synovial macrophage pyroptosis alleviates synovitis and fibrosis in knee osteoarthritis. Mediators Inflamm. https://doi.org/ $10.1155 / 2019 / 2165918$

Publisher's Note Springer Nature remains neutral with regard to jurisdictional claims in published maps and institutional affiliations. 